\title{
Training Situation and Effective Strategies for Active Applicants for Party Membership in Vocational Colleges
}

\author{
Peiyu Lin ${ }^{1, ~ a, ~ Y a n f e n ~ G a n ~}{ }^{2, ~ b}$, Junliu Zhong ${ }^{1, c}$ and Caiyan Lin ${ }^{1, d}$ \\ ${ }^{1}$ School of Information Engineering, Guangdong Mechanical \& Electrical College, Guangzhou \\ 510550, China; \\ ${ }^{2}$ School of Information Science and Technology, Guangdong University of Foreign Studies South \\ China Business College, Guangzhou 510545, China. \\ apeiyuLin633@163.com, bfannygyf@foxmail.com, cjunliuzhong@foxmail.com, dlincai9@sina.com
}

\begin{abstract}
Strengthening vocational active applicants' political thought learning and improving their own political consciousness as a new requirement is raised by the party committee. It is also a key issue to be faced and solved by vocational colleges. Therefore, analyzing the training situation of active applicants in vocational colleges, reforming and improving the education system, establishing sound training mechanism, and guiding the application of theory to practice is an effective strategies to improve the active applicants' comprehensive quality.
\end{abstract}

Keywords: Vocational colleges; active applicants; training situation; effective strategies.

\section{Introduction}

In recent years, with the continuous development of the vocational colleges and expansion of their enrollments, there have been an increasing number of students in school. So it becomes a priority in party building to develop and train party members among the students. It is clearly stated in the "Opinions of Organization Department of the CPC Central Committee on Further Improving the Party Member Development under New Situation" that the guiding principles for party member development are: Deng Xiaoping Theory; the important thought of Three Represents; "adherence to standards, quality assurance, structure improvement and careful development" ${ }^{[1]}$. Since vocational college students only study for two years in school, incomprehensive training for active applicants will probably result in two situations: one is that blind development of party members and that cannot guarantee the training quality of active applicants; the other is that delayed training of active applicants hinders the timely application of outstanding students. In order to solve these problems, it's necessary to discuss and analyze the training of active applicants.

\section{Training Situation of Active Applicants in Vocational Colleges}

At present, there are some problems with the training of active applicants in vocational colleges, which are mainly reflected in the following aspects. First of all, complicated motives for application make the training more difficult. With Chinese society's rapid development and progress, there have emerged diversified social values, because of which some students have lost their own judgment on social issues and values and some others may just gain "political capital" as an advantage for their future career ${ }^{[2]}$. As a result, their application becomes associated with personal interests. Second, the training and education is not specific enough. The numbers of active applicants have been gradually increased and the training levels have been enhanced. But it is also lack of the cultivate integrity and normalization. It has the serious trend to ' pay attention to training and neglect developing'. Third, students are not well equipped with the party's theoretical knowledge. In fact, political knowledge is a premise and basis for students to be qualified for application; political theories are an important guarantee for party members to maintain their progressiveness. But active applicants tend to regard ideological and political theories as simple learning content and thus lack a comprehensive understanding of the party's theoretical knowledge. Fourth, active applicants fail to lead by example. In vocational colleges, active applicants should be a dynamic team with outstanding performance in 
both school learning and social practice, but some of them have relaxed requirements for themselves due to inorganization and indiscipline in the team and thus fail to lead by example.

\section{Effective Strategies for Training of Active Applicants}

\subsection{Establish Rules and Regulations and Build an Effective Mechanism.}

Party building is the soul of college education ${ }^{[3]}$. For this, vocational colleges need to focus on grass-roots construction of active applicants. Above all, they should pay attention to organizational construction of active applicants by staffing excellent members for party affairs, sticking to grass-roots access system, and conducting regular training based on the actual situation of colleges. Then, they should proceed from their party office system and adapt it to the specific theoretical guidance and policy, so that new party members can regulate their own activities in the true sense. Next, vocational colleges need to establish a sound training system according to the characteristics of active applicants and ensure timely training for them in ideology, theory and practice. Last, but not the least, they need to establish a complete party admission system to help active applicants develop a training plan based on their own characteristics, center on the relationship between training and management, and effectively adjust the training for active applicants in all aspects .

\subsection{Strengthen Education and Improve Consciousness in Ideology and Politics.}

It is a priority in the training for active applicants to strengthen ideological and political education. And important approaches to such education include party school's basic knowledge training and league committee's theory training. As shown in Fig. 1, vocational colleges should strengthen intensive training and daily education so as to effectively improve the theoretical knowledge of active applicants ${ }^{[4]}$. For active applicants in vocational colleges, the most important thing is to study and understand the party admission constitution, read through party rules and constitution, recite the key theories, further understandings and explorations of the party's purpose, significance, goals and tasks. At the same time, they should be able to can make full use of Marxist ideas and methods to solve problems in their own learning and life, firmly believe in China's socialist theory and path, and take the lead in practicing socialist core values.

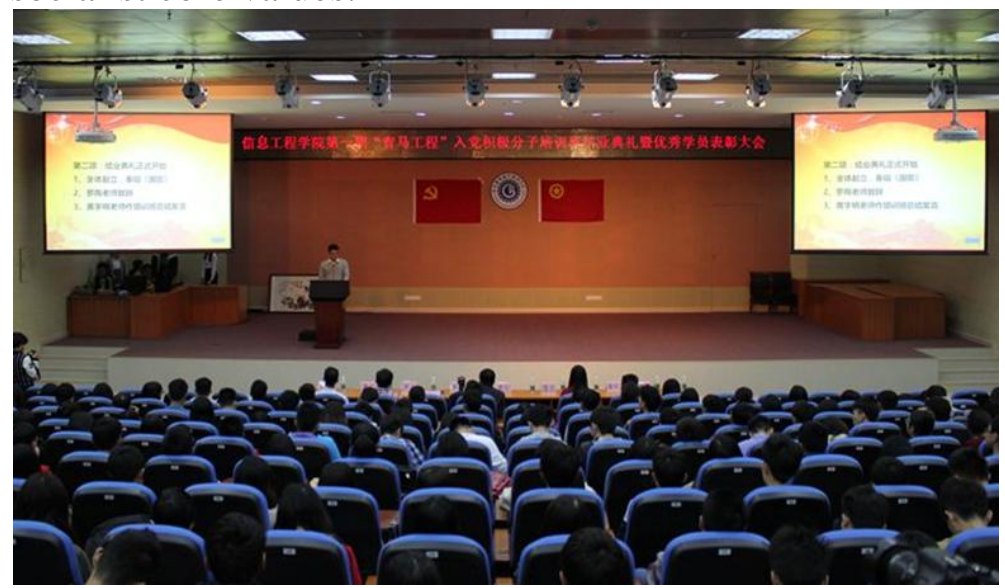

Fig. 1 Propaganda and Training Scene

\subsection{Study the Knowledge of the Party's History and the Revolution.}

Active applicants should fully understand the party's historical events and realistic goals. Currently, college students lack knowledge and understanding of Chinese revolutionary period and of Chinese glorious history in early 1990s. And living in the era of peace and abundance, some college students have lost the ability to pursue their own ideals. It is important to train their patriotic feelings and fine traditions, which can be achieved through the following two ways: one is the red memories, that is, the party office can take advantage of the red resources and adhere to the traditional revolutionary propaganda and education; the other is the red songs, that is, the party's revolutionary songs can be introduced into the training to touch and edify the students in mind and soul. 


\subsection{Emphasize Practice and Improve the Comprehensive Quality of Active Applicants.}

While helping students to establish a correct concept of the party admission, the training should focus on their practical ability and level. It can combine red theory and professional practice through the organization of various practical activities and the addition of fun, vivid practical training and education activities ${ }^{[5]}$. In order to improve the comprehensive quality of active applicants, the first thing is to insist on the training mode of combining the training with the party initiation education and associating daily learning with party affairs training. The second is to emphasize following-up education, which serves as an effective method for guiding active applicants to the political path and a valid way to link the party school's training with the party office's cultivation. And the third thing is that excellent instructors conduct professional guidance and training for active applicants so as to enhance students' overall quality and ability while effectively helping them learn theoretical knowledge.

\section{Conclusion}

Because training and education of active applicants for party membership is a long-term complex project for vocational colleges, the party office workers are required to possess good comprehensive quality and ability and strengthen themselves educational guidance to active applicants and constantly improve the relevance and effectiveness of education and training under the correct guidance of the party school's policy. From the above requirements, it will get better strategies for the sustainable cultivation of active applicants.

\section{Acknowledgments}

This work is supported by Guangdong Higher vocational education and teaching reform project (201401061) and Guangdong Province Party building in College Research project (2015GZYB29).

\section{References}

[1] "Opinions of Organization Department of the CPC Central Committee on Further Improving the Party Member Development under New Situation”. July 24, 2015, Party Building of Organs Directly under the Authority of the CPC Central Committee http://www. zzdjw.com/n/2015/0724/c240738-27356823.html.

[2] Liu Xiao. "Analysis of the Training Situation and Strategies for Active Applicants for Party Membership in Vocational Colleges" [J]. School Party Building and Ideological Education, 2012 (36): 12-14.

[3] Bai Xiangzhong. "On Training and Education of Active Applicants for Party Membership among Contemporary College Students" [D]. Shandong University, 2012: 6-17.

[4] Hao Cuirong \& Li Yiyong. "Survey and Analysis of Training Situation of Active Applicants for Party Membership among College Students" [J]. Shandong Youth Administrative Cadres College Journal, 2010 (05): 52-55

[5] Zhang Jing. "Analysis of Training and Management of Active Applicants for Party Membership in College Students" [J]. Reform \& Opening, 2011 (16): 104-105. 